Significance of Legumes for the Distribution of Plant Species in Grassland Ecosystems at Different Altitudes in the Alps

\author{
Journal Article \\ Author(s): \\ Jacot, Katja A.; Lüscher, Andreas; Suter, Matthias; Nösberger, Josef; Hartwig, Ueli A. \\ Publication date: \\ 2005-09 \\ Permanent link: \\ https://doi.org/10.3929/ethz-b-000031225 \\ Rights / license: \\ In Copyright - Non-Commercial Use Permitted \\ Originally published in: \\ Plant Ecology 180(1), https://doi.org/10.1007/s11258-004-7810-8
}




\title{
Significance of legumes for the distribution of plant species in grassland ecosystems at different altitudes in the Alps
}

\author{
Katja A. Jacot ${ }^{1,2}$, Andreas Lüscher ${ }^{1,2}$, Matthias Suter ${ }^{2}$, Josef Nösberger ${ }^{1}$ and Ueli A. \\ Hartwig ${ }^{1,3, *}$ \\ ${ }^{1}$ Institute of Plant Sciences, ETH-Zurich, 8092 Zurich, Switzerland; ${ }^{2}$ Swiss Federal Research Station for \\ Agroecology and Agriculture, Reckenholz, 8046 Zurich, Switzerland; ${ }^{3}$ Academia Engiadina, 7503 Samedan, \\ Switzerland; *Author for correspondence (e-mail: ueli.hartwig@academia-engiadina.ch; phone: +41-81-851- \\ 0677; fax: + 41-81-851-0646)
}

Received 6 June 2003; accepted in revised form 15 December 2004

Key words: High elevation, ${ }^{15} \mathrm{~N}$ natural abundance, Neighbouring species, Symbiotic nitrogen fixation

\begin{abstract}
The composition of plant species in grassland communities is determined in part by negative and positive interactions among neighbouring plants; such interactions could be dispersal or - in the case of legumes symbiotic $\mathrm{N}_{2}$ fixation or resource acquisition. We hypothesised that small scale distribution of plant species may be in part affected by (i) the plant's narrow dispersal in the close neighbourhood, (ii) by the $\mathrm{N}$ input into the soil through symbiotic $\mathrm{N}_{2}$ fixation by legumes, and (iii) by small scale heterogeneity of $\mathrm{N}$ availability in the soil. To address these hypotheses, in four species-rich semi-natural and natural grasslands along an altitudinal gradient from 900 to $2100 \mathrm{~m}$ a.s.l., the association of species that grew within a radius of $5 \mathrm{~cm}$ of selected plant species (central plant, CP) was studied. The distribution of the plant species within the plant community was not random and the species composition that grew within a radius of $5 \mathrm{~cm}$ of a $\mathrm{CP}$ varied with altitude. The strength of the association between a $\mathrm{CP}$ and its neighbouring species decreased with increasing altitude. The $5 \mathrm{~cm}$ radius was most dominated by individuals of the same species as the $\mathrm{CP}$, suggesting that narrow dispersal (either through seeds or through vegetative propagates) may be most important for the species composition within the sward. $\delta^{15} \mathrm{~N}$ values of non leguminous species growing near legumes compared to non leguminous species that grew far from legumes indicate that $\mathrm{N}$ from symbiotic $\mathrm{N}_{2}$ fixation may be another factor influencing the association of plant species. Effects of small scale heterogeneity in apparent $\mathrm{N}$ availability in the soil were detected to be the least important for the species composition.
\end{abstract}

\section{Introduction}

In natural environments, the distribution of living organisms is usually patchy, arranged along gradients or in combination of both. The species composition of plant communities is determined in part by negative and positive interactions among neighbouring plants. Differences in the plant's demand for resources, in the pattern of growth, propagation and the way in which species modify the environment for other plant species may all contribute to the spatial pattering in a plant community (Callaway 1995). On the other hand small scale differences or gradients in the physical environment may lead to associations of plant species which all grow well under particular 
micro-environmental conditions. Turkington and Harper (1979a; 1979b) and Turkington et al. (1985) showed many interspecific, though mainly negative associations in a small area. Few studies have revealed that slight differences in the frequency of species or genotypes of plants may be related to differences in the physical environment (Turkington et al. 1979a) or in the plant species that grow nearby (Turkington 1989; Lüscher et al. 1992) or to a combination of both (Turkington 1989). In alpine regions, a considerable variability in the environmental conditions over a small area is assumed. Moreover, specific climatic and edaphic conditions require particular strategies of plants for growth. Thus plant-plant and plantenvironment interactions may be important for the structure of permanent grassland communities such as alpine grasslands (Kikvidze 1993; Bertness and Callaway 1994; Callaway 1995; Hacker and Gaines 1997).

Insufficient supply of $\mathrm{N}$ substantially limits plant growth in many terrestrial ecosystems (Vitousek and Howarth 1991). Thus, the role of symbiotic $\mathrm{N}_{2}$ fixation in structuring plant communities and its effect on the ecosystem may be considerable. Symbiotic $\mathrm{N}_{2}$ fixation is an important component of the $\mathrm{N}$ balance of various legume species in the Alps, which acquire 59 to $90 \%$ of $\mathrm{N}$ from symbiotic $\mathrm{N}_{2}$ fixation up to the upper limit at which they can grow (Jacot et al. 2000a). The amount of $\mathrm{N}$ that is apparently transferred from legumes to non leguminous species may be as much as $80 \mathrm{~kg} \mathrm{~N} \mathrm{ha}^{-1} \mathrm{a}^{-1}$ in low land grassland ecosystems (Boller and Nösberger 1988; Hogh-Jensen and Schjoerring 1994; Seresinhe et al. 1994; Zanetti et al. 1997); a beneficial effect of leguminous plants on the growth of the non leguminous companion plants was clearly shown by Hebeisen et al. (1997) under low-land conditions. Many studies have shown the importance of plants that symbiotically fix $\mathrm{N}_{2}$ in primary successional series (Lawrence et al. 1967; Morris and Wood 1989; Chapin et al. 1994). Moreover, Thomas and Bowman (1998) found an apparent effect of legumes on the pattern of plant species in permanent alpine grassland; both facilitative and inhibitive effects of Trifolium were found.

Most work on possible positive and negative interactions between neighbouring plants was based on the statistical association between pairs of species (e.g., Kershaw 1958, 1959; Turkington and Harper 1979a; 1979b). These patterns of association can be described either by an analysis of covariance or by correlation coefficients. In this study, we developed a 'plant-centred' sampling method to study all the neighbouring plant species within $5 \mathrm{~cm}$ of different plant species as central plant (CP). Analysing these neighbourhoods by means of the logistic regression technique enabled us to include all the neighbouring plant species in the same analyses as compared to the analysis of pairs of plant species only. The frequency of plant species near legume CPs was compared with that of plant species around non leguminous CPs. With the selection of non leguminous CPs with a high and a low $\mathrm{N}$ indicator value respectively we aimed to cover a larger range of small scale variability of the physical environment within each site.

The goal of this work was to determine whether the frequency of species is related to the plant species that grow nearby or to the physical environment or to a combination of both. Effects of the CPs on the species frequency in their neighbourhood were expected to be related to (i) narrow seed or vegetative dispersal (the same species as the $\mathrm{CP}$ would be dominant in the near neighbourhood) or (ii) increased $\mathrm{N}$ availability in the close neighbourhood of legumes. ${ }^{15} \mathrm{~N}$ natural abundance was measured to provide information about apparent transfer of $\mathrm{N}$ between legumes and non leguminous species in their close neighbourhood. (iii) Association of plants which all grow well under particular physical environmental conditions would be visible in a low and high $\mathrm{N}$ indicator value of the neighbouring plant of the respective $\mathrm{N}$ indicator $\mathrm{CPs}$.

\section{Materials and methods}

\section{Sites}

The experiments were conducted on a southern slope in the upper Rhine valley, between Sumvitg and Trun (approximately $45 \mathrm{~km}$ to the south-west of Chur in the eastern Alps of Switzerland; $46^{\circ} 45^{\prime}$, $\left.8^{\circ} 57^{\prime} \mathrm{E}\right)$ at four altitudes $(900,1380,1900$ and $2100 \mathrm{~m}$ a.s.1). All the studies were made on natural permanent grassland, where Gneiss (consisting of granite) dominates. The sites were described in detail by Jacot et al. (2000a). 
Before the investigation began, the sites at 900 and $1380 \mathrm{~m}$ a.s.l. were mown in the traditional way in the summer and grazed late in the autumn. The higher sites were grazed only during the summer.

\section{Coexistence studies}

To assess the spatial pattern within a plant community, the plant species in the nearest neighbourhood $(<5 \mathrm{~cm})$ around selected individuals were recorded in 1996 and 1997. Except at $2100 \mathrm{~m}$ a.s.1., recording began two weeks after the first mowing at each altitude: end of June at $900 \mathrm{~m}$ a.s.1., beginning of July at $1380 \mathrm{~m}$ a.s.1., beginning of August at $1900 \mathrm{~m}$ a.s.l. and midAugust at $2100 \mathrm{~m}$ a.s.1. (before mowing). At each altitude one study area $\left(100 \mathrm{~m}^{2}\right)$ was selected and was divided into 50 subplots, $2 \mathrm{~m}^{2}$ each. In each of 40 subplots chosen from the 50 subplots, two legume species (Trifolium pratense/nivale, Lotus corniculatus/alpinus), one non leguminous species indicating N-rich conditions (Landolt 1977) and one non leguminous species indicating $\mathrm{N}$-poor conditions were chosen as central plants (CP). At $2100 \mathrm{~m}$ a.s.1., no non leguminous species indicating $\mathrm{N}$ rich conditions were chosen due to low abundance of high $\mathrm{N}$ indicators. Instead, two non leguminous species indicating $\mathrm{N}$-poor conditions were selected as CPs. In each of the $2 \mathrm{~m}^{2}$ subplots, one plant of each of the four different species (CPs) near to the centre of the subplot was chosen. All plant species within a radius of $5 \mathrm{~cm}$ of the $\mathrm{CP}$ were recorded separately in eight equal sectors. If a plant species was found in several sectors it was recorded once in each sector. Thus, one species may be recorded from 0 (did not occur) to 8 times (was found in each sector) in the neighbourhood of each individual CP. At each of the four sites, the neighbourhood of a total of 320 individual CPs ( 2 years $\times 4$ CPs $\times 40$ replicates) was examined.

\section{${ }^{15} \mathrm{~N}$ natural abundance}

At all altitudes, three randomly selected non leguminous species from positions immediately neighbouring to legumes and in an area far from legumes $\left(0.25 \mathrm{~m}^{2}\right)$ and legumes themselves were sampled (see also Table 3$)$. All the dried $\left(65^{\circ} \mathrm{C}\right.$ for $48 \mathrm{~h}$ ) plant material was ground to very fine powder in sequence using a Cyclotec 1093 sample mill (Tecator, Höganäs, Sweden) and a ball mill (type MM2; Retsch, Arlesheim, Switzerland). After drying again $\left(35^{\circ} \mathrm{C}\right.$ for $\left.24 \mathrm{~h}\right)$, the samples $(2 \mathrm{mg})$ were weighed into tin caps $(0.04 \mathrm{ml}$, Lüdi, Flawil, Switzerland) and analysed for ${ }^{15} \mathrm{~N}$ concentration using a continuous-flow mass spectrometer (Europa Scientific, Cambridge, UK) at the Stable Laboratory Facility of the University of Saskatchewan, Saskatoon, Canada. The precision of the natural abundance mass spectrometer was \pm 0.3 delta per mil.

When determining small differences in the ${ }^{15} \mathrm{~N}$ concentration, data are usually recorded as $\delta^{15} \mathrm{~N}$ (\%o) (Shearer and Kohl 1986), which is defined as follows:

$$
\begin{aligned}
& \delta^{15} \mathrm{~N}(\%) \\
& =\left(\frac{\text { atom } \%{ }^{15} \mathrm{~N}(\text { sample })-\text { atom } \%{ }^{15} \mathrm{~N}(\text { standard })}{\text { atom } \%{ }^{15} \mathrm{~N}(\text { standard })}\right) \\
& * 1000,
\end{aligned}
$$

(The standard is atmospheric $\mathrm{N}_{2}$ )

\section{Soil nitrogen $(N)$ and temperature $(T)$ indicator values}

The Swiss flora has been classified empirically according to various environmental parameters (e.g., soil $\mathrm{N}$ status, temperature, soil $\mathrm{pH}$, soil water content); five categories reflect a mixture of physiological characteristic and frequency of occurrence under particular conditions (Landolt 1977). This classification may help to classify growing conditions of a plant community. Low $\mathrm{N}$ indicator values indicate that these plants occur mainly at nutrientpoor sites while high values indicate main occurrence at very rich sites. Low $T$ indicator values indicate that these plants occur mainly under relatively low temperatures while high values indicate main occurrence at warm climatic conditions.

At all four sites, $\mathrm{N}$ and $T$ indicator values (Landolt 1977) were recorded weighted for all species growing within a $5 \mathrm{~cm}$ radius of each $\mathrm{CP}$ (see Table 2).

\section{Data analyses}

The association of the neighbouring species and a particular $\mathrm{CP}$ was analysed with logistic regression 
(LOGISTIC procedure in SAS; SAS Institute, Cary, NC, USA). Four different regressions were performed per altitude, each for one CP. For a particular regression, the value of the target $\mathrm{CP}$ was defined as 1 at recordings for that $\mathrm{CP}$, while it was 0 for the recordings of the three remaining CPs. The present-absent data of the neighbouring species were used as explanatory variables. This procedure enabled to calculate a probability of a $\mathrm{CP}$ being present at the presence of a set of species in the close environment.

In a first analysis (model A), only the same species as the four CPs were used as explanatory variables resulting in a first set of 16 regressions (4 CPs $\times 4$ altitudes). In a further analysis (model B), we aimed to assess a characteristic set from all the neighbour species which could predict the occurrence of the CPs. Thus, additional species were included as explanatory variables by a stepwise procedure. In these regressions, only neighbour species which reached a significance level of $p \leq 0.10$ were included in the final model. The exception was the same species as the four CPs, which remained always in the model. In all the regressions, species with less than ten records per site (altitude) were not included in the analysis.

${ }^{15} \mathrm{~N}$ natural abundance data were analysed with ANOVA applying the GLM procedure of SAS. The nitrogen and temperature indicator values (Landolt 1977) of the neighbourhoods of the CPs were tested with the Kruskal-Wallis test for nonparametric multiple comparisons.

\section{Results}

\section{Coexistence studies}

A total of 97 plant species were recorded over the two years (Table 1). The species were not randomly distributed. The four species chosen as central plants (CP) were usually associated with a characteristic set of plant species that influenced the presence of the $\mathrm{CP}$ positively or negatively (Table 2a-d).

For example, at $900 \mathrm{~m}$ a.s.l. the probability of Trifolium pratense being the $\mathrm{CP}$ was increased by the presence of Trifolium pratense itself, Arrhenaterum elatius, Lolium perenne, Salvia pratensis, and Trisetum flavescens, (higher probability of these species compared to the intercept; Table 2a,
Table 1. Plant species at the experimental sites at four altitudes between 900 and $2100 \mathrm{~m}$ a.s.l.

\begin{tabular}{|c|c|c|c|c|}
\hline \multicolumn{5}{|l|}{ Altitude (m a.s.l.) } \\
\hline Species & 900 & 1380 & 1900 & 2100 \\
\hline Agropyron repens & $\mathrm{X}$ & $\mathrm{X}$ & & \\
\hline Agrostis tenuis & $\mathrm{X}$ & $\mathrm{X}$ & $\mathrm{X}$ & $\mathrm{X}$ \\
\hline Anthoxantum alpinum & & & & $\mathrm{X}$ \\
\hline Anthoxantum odoratum & $\mathrm{X}$ & $\mathrm{X}$ & $\mathrm{X}$ & \\
\hline Arrhenaterum elatius & $\mathrm{X}$ & $\mathrm{X}$ & . & \\
\hline Avena pubescens & & & & $\mathrm{X}$ \\
\hline $\begin{array}{l}\text { Cynosurus cristatus } \\
\text { Dactylis glomerata }\end{array}$ & $\begin{array}{l}X \\
X\end{array}$ & $\begin{array}{l}X \\
X\end{array}$ & $\mathrm{X}$ & \\
\hline & $\mathrm{X}$ & $\mathrm{X}$ & . & $\mathrm{X}$ \\
\hline Festuca pratensis & $\mathrm{X}$ & $\mathrm{X}$ & & \\
\hline Festuca rubra & $\mathrm{X}$ & $\mathrm{X}$ & $\mathrm{X}$ & $\mathrm{X}$ \\
\hline Holcus lanatus & $\mathrm{X}$ & $\mathrm{X}$ & & \\
\hline Lolium perenne & $\mathrm{X}$ & $\mathrm{X}$ & $\mathrm{X}$ & \\
\hline Nardus stricta & & . & $\mathrm{X}$ & $\mathrm{X}$ \\
\hline Phleum alpinum & & . & $\mathrm{X}$ & $\mathrm{X}$ \\
\hline Poa alpina & & & $\mathrm{X}$ & $\mathrm{X}$ \\
\hline Роа аппиа & $\mathrm{X}$ & $\mathrm{X}$ & $\mathrm{X}$ & \\
\hline Poa pratensis & $\mathrm{X}$ & $\mathrm{X}$ & . & \\
\hline Poa supina & $e^{\prime}$ & . & . & $\mathrm{X}$ \\
\hline Trisetum flavescens & & $\mathrm{X}$ & & \\
\hline Carex $s p$ & $\mathrm{X}$ & $\mathrm{X}$ & $\mathrm{X}$ & $\mathrm{X}$ \\
\hline Luzula sudetica & . & . & $\mathrm{X}$ & \\
\hline Lotus alpinus & & & & $\mathrm{X}$ \\
\hline Lotus corniculatus & $\mathrm{X}$ & $\mathrm{X}$ & $\mathrm{X}$ & \\
\hline Trifolium alpinum & & . & $\mathrm{X}$ & $\mathrm{X}$ \\
\hline Trifolium badium & & & 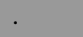 & $\mathrm{X}$ \\
\hline Trifolium medium & & $\mathrm{X}$ & & \\
\hline Trifolium nivale & & & & $\mathrm{X}$ \\
\hline Trifolium pratense & $\mathrm{X}$ & $\mathrm{X}$ & $\mathrm{X}$ & \\
\hline Trifolium repens & $\mathrm{X}$ & $\mathrm{X}$ & $\mathrm{X}$ & . \\
\hline Trifolium thalii & & & $\mathrm{X}$ & \\
\hline Vicia sativa & $\mathrm{X}$ & $\mathrm{X}$ & & \\
\hline Achillea millefolium & $\mathrm{X}$ & $\mathrm{X}$ & $\mathrm{X}$ & \\
\hline Aegopodium podagraria & & $\mathrm{X}$ & . & . \\
\hline Ajuga genevensis & $\mathrm{X}$ & . & . & . \\
\hline Ajuga pyramidalis & . & $\mathrm{X}$ & $\mathrm{X}$ & . \\
\hline Alchemilla vulgaris & & $\mathrm{X}$ & $\mathrm{X}$ & . \\
\hline Arabis hirsuta & $\mathrm{X}$ & . & & \\
\hline Arnica montana & . & . & $\mathrm{X}$ & $\mathrm{X}$ \\
\hline Bellis perennis & . & $\mathrm{X}$ & . & \\
\hline Calluna vulgaris & . & . & & $\mathrm{X}$ \\
\hline Campanula barbata & & 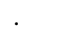 & $\mathrm{X}$ & $\mathrm{X}$ \\
\hline Campanula rotundifolia & $\mathrm{X}$ & $\mathrm{X}$ & $\mathrm{X}$ & \\
\hline Carum carvi & & . & . & $\mathrm{X}$ \\
\hline Cerastium caespitosum & $\mathrm{X}$ & $\mathrm{X}$ & $\mathrm{X}$ & $\mathrm{X}$ \\
\hline Chrysanthemum leucanthemum & $\mathrm{X}$ & $\mathrm{X}$ & . & \\
\hline Crepis aurea & . & . & . & $\mathrm{X}$ \\
\hline Crepis biennis & & $\mathrm{X}$ & . & \\
\hline Echium vulgare & $\mathrm{X}$ & . & . & \\
\hline Euphrasia minima & . & . & $\mathrm{X}$ & $\mathrm{X}$ \\
\hline Galium anisophyllum & . & . & $\mathrm{X}$ & $\mathrm{X}$ \\
\hline Galium mollugo & $\mathrm{X}$ & $\mathrm{X}$ & & \\
\hline Gentiana kochiana & $\cdot$ & . & $\mathrm{X}$ & $\mathrm{X}$ \\
\hline Geranium silvaticum & . & . & . & $\mathrm{X}$ \\
\hline
\end{tabular}


Table 1. Continued.

\begin{tabular}{|c|c|c|c|c|}
\hline \multicolumn{5}{|l|}{ Altitude (m a.s.l.) } \\
\hline Species & 900 & 1380 & 1900 & 2100 \\
\hline Geum montanum & . & . & $\mathrm{X}$ & $\mathrm{X}$ \\
\hline Gnaphallium silvaticum & . & . & $\mathrm{X}$ & $\mathrm{X}$ \\
\hline Heracleum sphondylium & . & $\mathrm{X}$ & . & \\
\hline Hieracium alpinum & . & . & . & $\mathrm{X}$ \\
\hline Hieracium pilosella & . & . & $\mathrm{X}$ & $\mathrm{X}$ \\
\hline Homogyne alpina & . & . & . & $\mathrm{X}$ \\
\hline Hypericum maculatum & . & . & $\mathrm{X}$ & . \\
\hline Hypochoeris radicata & $\mathrm{X}$ & $\mathrm{X}$ & . & \\
\hline Knautia arvensis & $\mathrm{X}$ & $\mathrm{X}$ & . & \\
\hline Leontodon helveticus & . & . & $\mathrm{X}$ & $\mathrm{X}$ \\
\hline Leontodon hispidus & $\mathrm{X}$ & $\mathrm{X}$ & . & \\
\hline Myosotis alpestris & . & . & . & $\mathrm{X}$ \\
\hline Myosotis silvatica & $\mathrm{X}$ & $\mathrm{X}$ & . & \\
\hline Phyteuma betonicifolia & $\mathrm{X}$ & $\mathrm{X}$ & $\mathrm{X}$ & $\mathrm{X}$ \\
\hline Plantago lanceolata & $\mathrm{X}$ & $\mathrm{X}$ & $\mathrm{X}$ & \\
\hline Potentilla aurea & . & . & $\mathrm{X}$ & $\mathrm{X}$ \\
\hline Potentilla erecta & . & . & $\mathrm{X}$ & $\mathrm{X}$ \\
\hline Ranunculus alpestris & . & . & $\mathrm{X}$ & 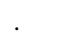 \\
\hline Ranunculus bulbosus & $\mathrm{X}$ & . & . & \\
\hline Ranunculus friesianus & . & $\mathrm{X}$ & . & . \\
\hline Rhinantus alectorolophus & $\mathrm{X}$ & $\mathrm{X}$ & . & \\
\hline Rumex acetosa & $\mathrm{X}$ & $\mathrm{X}$ & $\mathrm{X}$ & $\mathrm{X}$ \\
\hline Rumex acetosella & . & $\mathrm{X}$ & . & \\
\hline Rumex obtusifolius & . & . & . & $\mathrm{X}$ \\
\hline Salvia pratensis & $\mathrm{X}$ & $\mathrm{X}$ & . & \\
\hline Satureja vulgaris & $\mathrm{X}$ & $\mathrm{X}$ & . & \\
\hline Sempervirum montanum & . & . & . & $\mathrm{X}$ \\
\hline Silene alba & $\mathrm{X}$ & $\mathrm{X}$ & . & . \\
\hline Silene nutans & . & . & $\mathrm{X}$ & \\
\hline Silene vulgaris & $\mathrm{X}$ & $\mathrm{X}$ & . & $\mathrm{X}$ \\
\hline Soldanella pusilla & . & . & . & $\mathrm{X}$ \\
\hline Solidago alpestris & . & 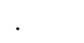 & . & $\mathrm{X}$ \\
\hline Taraxacum officinale & $\mathrm{X}$ & $\mathrm{X}$ & . & . \\
\hline Thymus humifusus & . & . & $\mathrm{X}$ & \\
\hline Thymus polytrichus & - & . & . & $\mathrm{X}$ \\
\hline Thymus pulegioides & $\mathrm{X}$ & $\mathrm{X}$ & 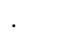 & \\
\hline Vaccinium myrtillus & . & . & $\mathrm{X}$ & $\mathrm{X}$ \\
\hline Vaccinium uliginosum & . & . & . & $\mathrm{X}$ \\
\hline Vaccinium vitis & . & . & . & $\mathrm{X}$ \\
\hline Veronica chamaedris & $\mathrm{X}$ & $\mathrm{X}$ & $\mathrm{X}$ & . \\
\hline Veronica officinalis & . & . & $\mathrm{X}$ & . \\
\hline Viola tricolor & $\mathrm{X}$ & $\mathrm{X}$ & $\cdot$ & \\
\hline Botrychium lunaria & . & . & . & $\mathrm{X}$ \\
\hline
\end{tabular}

Plant nomenclature according to Hess et al. (1984) ( $\underline{\text { grami- }}$ noids, $\square$ legumes, $\square$ non-legume dicots).

Model B). In contrast, the presence of Lotus corniculatus, Dactylis glomerata, Silene vulgaris, Festuca rubra, and Trifolium repens decreased the probability of Trifolium pratense being the $\mathrm{CP}$ (lower probability of these species compared to the intercept; Table 2a, Model B).
Patterns of associations of CPs with neighbour species varied with altitude. For example, at $900 \mathrm{~m}$ a.s.l. the CP Lotus corniculatus was positively associated with the presence of Lotus corniculatus, Agrostis tenuis, Arrhenaterum elatius, and Festuca rubra in the neighbourhood, while it was negatively associated with Trifolium pratense and Silene vulgaris. In comparison, at $1900 \mathrm{~m}$ a.s.l. the CP L. corniculatus was positively associated withLotus corniculatus, Potentilla erecta, Agrostis tenuis, Leontodon helveticus, and Nardus stricta, while it was negatively associated with the presence of Trifolium pratense.

Only a few associations were found along a wider altitudinal gradient: Agrostis tenuis was one of the characteristic species in the neighbourhood of Lotus corniculatus at three altitudes (from 900 to $1900 \mathrm{~m}$ a.s.1.), and Lolium perenne was one of the characteristic species associated with Trifolium pratense at 900 and $1380 \mathrm{~m}$ a.s.l.

As evident from the generally decreasing $R^{2}$ values with increasing altitude, the strength of the association between a $\mathrm{CP}$ and neighbouring plants decreased with increasing altitude (Table 2a-d). Moreover, the number of plants that predicted (positively or negatively) the presence of the CPs clearly decreased with altitude.

In many cases, a $\mathrm{CP}$ was best characterised by the neighbourhood of individuals of the same species (see diagonal of the associations for the four CPs; e.g. in Table 2a, Model A and B). The CP Trifolium pratense/nivale was positively associated with other individuals of Trifolium pratense/nivale even at all four sites (from 900 to $2100 \mathrm{~m}$ a.s.1.). Similarly, the CP Lotus corniculatus was positively associated with other individuals of Lotus corniculatus at three sites (from 900 to $1900 \mathrm{~m}$ a.s.1.). This relationship is also revealed when the models A (only the same predictor as the four CPs) are compared with models B (all species potentially included as predictors). Though in most cases the models B explained significantly more variance than the reduced models A (likelihood ratio test), there was often only a minor increase in the $R^{2}$ value in model B compared to model A.

\section{${ }^{15} \mathrm{~N}$ natural abundance}

$\delta^{15} \mathrm{~N}$ of the legumes was always close to 0 (Table 3). At the four sites between 900 and 
Table 2. Backtransformed probabilities of logistic regression for the prediction of the central plant (CP) through the neighbouring plants (radius of $5 \mathrm{~cm}$ ) at the altitude of $\mathbf{9 0 0} \mathbf{~ m}$ a.s.l. $(900 \mathrm{~m}$ ).

\begin{tabular}{|c|c|c|c|c|c|}
\hline Central plant & Trifolium pratense & Lotus corniculatus & Dactylis glomerata & Silene vulgaris & \\
\hline $\mathrm{N}$ indicator value $\mathrm{a}^{\mathrm{a}}$ & 3 & 3 & 4 & 2 & $n$ \\
\hline Model A, Intercept & $0.298 * * * *$ & $0.169^{* * * *}$ & $0.270^{* * * *}$ & $0.320 * * *$ & \\
\hline Trifolium pratense & $0.675^{* * * *}$ & $0.048 * *$ & $0.147^{* *}$ & $0.161^{* *}$ & 135 \\
\hline Lotus corniculatus & $0.021 * *$ & $0.540 * * * *$ & $0.099 * * *$ & $0.202^{* *}$ & 166 \\
\hline Dactylis glomerata & $0.200^{* *}$ & $0.149 \mathrm{~ns}$ & $0.417 * * * *$ & $0.196^{* *}$ & 220 \\
\hline Silene vulgaris & $0.053^{*}$ & $0.013 * * * *$ & $0.058 \dagger$ & $0.852 * * * *$ & 77 \\
\hline Model B, Intercept & $0.322 *$ & $0.074 * * * *$ & $0.274 * * * *$ & $0.428 \mathrm{~ns}$ & \\
\hline Trifolium pratense & $0.697 * * * *$ & $0.019 * *$ & $0.150^{* *}$ & $0.208^{*}$ & 135 \\
\hline Lotus corniculatus & $0.012 * *$ & $0.340^{* * * *}$ & $0.100^{* * *}$ & $0.296^{*}$ & 166 \\
\hline Dactylis glomerata & $0.200^{* * *}$ & $0.065 \mathrm{~ns}$ & $0.422^{* * * *}$ & $0.275^{* *}$ & 220 \\
\hline Silene vulgaris & $0.071^{*}$ & $0.005^{* * * *}$ & $0.048^{*}$ & 0.973**** & 77 \\
\hline Agrostis tenuis & - & $0.096^{*}$ & - & - & 306 \\
\hline Arrhenaterum elatius & $0.454^{*}$ & $0.147^{* * *}$ & - & $0.164 * * *$ & 135 \\
\hline Festuca rubra & $0.097 *$ & $0.152^{*}$ & $0.392 \dagger$ & $0.228 \dagger$ & 58 \\
\hline Leontodon hispidus & - & - & - & $0.328^{*}$ & 140 \\
\hline Lolium perenne & $0.433^{*}$ & - & - & $0.329^{*}$ & 143 \\
\hline Salvia pratensis & $0.453 \dagger$ & - & - & - & 53 \\
\hline Trifolium repens & $0.220 * * *$ & - & - & $0.475 \dagger$ & 388 \\
\hline Trisetum flavescens & $0.399 \dagger$ & - & - & - & 128 \\
\hline$p$-value (Model A) & $* * * *$ & $* * * *$ & $* * * *$ & $* * * *$ & \\
\hline$R^{2}($ Model A) & 51.8 & 54.9 & 36.2 & 42.6 & \\
\hline$p$-value (Model B) & $* * * *$ & $* * * *$ & $* * * *$ & $* * * *$ & \\
\hline$R^{2}$ (Model $\left.\mathrm{B}\right)$ & 61.2 & 61.1 & 37.2 & 53.1 & \\
\hline Likelihood ratio test (Model A versus B) & $* * * *$ & $* * * *$ & $\dagger$ & $* * * *$ & \\
\hline
\end{tabular}

ns: $p>0.1 ; \dagger p \leq 0.1 ;{ }^{*} p \leq 0.05 ; * p \leq 0.01 ; * * * \leq \leq 0.001 ; * * * p \leq 0.0001 ;-:$ term was not included in the final model. ${ }^{\mathrm{a}}$ Landolt (1977)

In model A, only the same species as the four CPs were evaluated as predictor species (neighbour species). In model B, additional neighbour species with distinct effects $(p<0.1)$ were selected by a stepwise procedure. The backtransformed coefficients are the probability of presence of the $\mathrm{CP}$ when the predictor species is present. A probability higher than the intercept means a positive association between neighbour and CP; a probability lower than the intercept indicates a negative association. ' $n$ ' indicates total records of each species of a maximum of 2560 ( 2 years $\times 4 \mathrm{CPs} \times 8$ sectors $\times 40$ reps.). Bold are the same neighbour species as the $\mathrm{CP}$.

$2100 \mathrm{~m}$ a.s.1., the $\delta^{15} \mathrm{~N}$ values of the non leguminous species differed, depending on whether they grew in the immediate neighbourhood of a legume (near legumes) or in an area far from legumes (Table 3). With the exception of the site at $1380 \mathrm{~m}$ a.s.l., non leguminous plant species always had a $\delta^{15} \mathrm{~N}$ value closer to zero near a leguminous plant species than in an area far from legumes.

\section{$N$ and $T$ indicator values}

At 900 and $1900 \mathrm{~m}$ a.s.l. the $\mathrm{N}$ indicator value (Landolt 1977) of all associated species differed significantly among the central plants (Table 4a). The values were highest close to the legumes and the $\mathrm{N}$ indicator at $900 \mathrm{~m}$ a.s.l.
The $T$ indicator values decreased from 900 to $2100 \mathrm{~m}$ a.s.1. (Table $4 \mathrm{~b}$ ). At $2100 \mathrm{~m}$ a.s.1., the $T$ values of the plants around Trifolium nivale were lower than the $T$ values around the other CPs.

\section{Discussion}

The frequency of some of the species varied according to the neighbouring plants (Table 2), indicating that there may be positive and/or negative interactions among plants. Our data indicate that narrow-range dispersal and soil $\mathrm{N}$, the latter presumably in part influenced by symbiotic $\mathrm{N}_{2}$ fixation in legumes, may affect the pattern of species in grassland ecosystems from 900 to $2100 \mathrm{~m}$ a.s.l. However, one has to bear in mind that our data 
Table 3. Backtransformed probabilities of logistic regression for the prediction of the central plant $(\mathrm{CP})$ through the neighbouring plants (radius of $5 \mathrm{~cm}$ ) at the altitude of $\mathbf{1 3 8 0} \mathbf{~ m}$ a.s.l. $(1380 \mathrm{~m}$ ).

\begin{tabular}{|c|c|c|c|c|c|}
\hline Central plant & Trifolium pratense & Lotus corniculatus & Dactylis glomerata & Silene vulgaris & \\
\hline $\mathrm{N}$ indicator value $\mathrm{a}^{\mathrm{a}}$ & 3 & 3 & 4 & 2 & $n$ \\
\hline Model A, Intercept & $0.244 * * * *$ & $0.154 * * * *$ & $0.332 * * *$ & $0.316^{* * * *}$ & \\
\hline Trifolium pratense & $0.529 * * * *$ & $0.076^{*}$ & $0.221 *$ & $0.131 *$ & 92 \\
\hline Lotus corniculatus & $0.165 \mathrm{~ns}$ & $0.331 * * * *$ & $0.246 \dagger$ & $0.124^{*}$ & 84 \\
\hline Dactylis glomerata & $0.215 \mathrm{~ns}$ & $0.188^{* *}$ & 0.322 ns & $0.281^{*}$ & 526 \\
\hline Silene vulgaris & $0.124 \dagger$ & $0.147 \mathrm{~ns}$ & $0.178^{*}$ & $0.551^{* * * *}$ & 70 \\
\hline Model B, Intercept & $0.154 * * * *$ & $0.082^{* * * * *}$ & $0.487 \mathrm{~ns}$ & $0.372 *$ & \\
\hline Trifolium pratense & $0.426 * * * *$ & $0.034 *$ & $0.345^{*}$ & $0.160^{* *}$ & 92 \\
\hline Lotus corniculatus & $0.100^{*}$ & $\mathbf{0 . 2 3 0} * * * *$ & $0.403 \mathrm{~ns}$ & $0.152^{*}$ & 84 \\
\hline Dactylis glomerata & $0.152 \mathrm{~ns}$ & $0.105^{* * *}$ & $0.476 \mathrm{~ns}$ & $0.333^{*}$ & 526 \\
\hline Silene vulgaris & $0.080 \dagger$ & $0.066 \mathrm{~ns}$ & $0.293^{*}$ & $0.617 * * * *$ & 70 \\
\hline Achillea millefolium & - & - & - & $0.310^{*}$ & 325 \\
\hline Agrostis tenuis & - & $0.098^{* *}$ & $0.451^{*}$ & - & 958 \\
\hline Cynosurus cristatus & - & $0.035 \dagger$ & $0.615^{*}$ & - & 58 \\
\hline Leontodon hispidus & - & - & $0.390 \dagger$ & - & 141 \\
\hline Lolium perenne & $0.180 \dagger$ & - & $0.354 \dagger$ & - & 105 \\
\hline Plantago lanceolata & $0.197^{*}$ & $0.058^{*}$ & - & - & 226 \\
\hline Poa pratensis & $0.201^{*}$ & - & $0.376 \dagger$ & - & 96 \\
\hline Trifolium repens & - & $0.092 \dagger$ & - & - & 482 \\
\hline Trisetum flavescens & - & $0.097 \dagger$ & - & - & 204 \\
\hline$p$-value (Model A) & $* * * *$ & $* * * *$ & $* * *$ & $* * * *$ & \\
\hline$R^{2}($ Model A) & 26.1 & 23.1 & 8.2 & 21.3 & \\
\hline$p$-value (Model B) & $* * * *$ & $* * * *$ & $* * * *$ & $* * * *$ & \\
\hline$R^{2}($ Model $\mathrm{B})$ & 29.9 & 34.2 & 19.4 & 23.1 & \\
\hline Likelihood ratio test (Model A versus B) & * & $* * * *$ & $* * * *$ & * & \\
\hline
\end{tabular}

ns: $p>0.1 ; \dagger p \leq 0.1 ;{ }^{*} p \leq 0.05 ;{ }^{* *} p \leq 0.01 ;{ }^{* * *} p \leq 0.001 ; * * * p \leq 0.0001 ;-:$ term was not included in the final model. ${ }^{\mathrm{a}}$ Landolt (1977)

In model A, only the same species as the four CPs were evaluated as predictor species (neighbour species). In model B, additional neighbour species with distinct effects $(p<0.1)$ were selected by a stepwise procedure. Further details see Table 2a.

cannot fully explain how plant species influence each others growth in grassland ecosystems.

\section{Narrow dispersal as one possible determinant of plant community structure}

Neighbouring plants of the same species as the $\mathrm{CP}$ often grow close to the CP (Table 2). Many of these plants were seedlings, indicating either that seed dispersal was limited in distance or that conditions were favourable there for plant establishment, or both. Most of the CPs have large seeds (e.g., Trifolium pratense and Lotus corniculatus), which indicates limited distance in seed dispersal; thus, species patterning may also be affected by seed dispersal. This interpretation is supported by the finding that the patchiness of seed banks corresponds to the patchiness of surface plants (Cabin and Marshall 2000).
Beside seed dispersal, vegetative propagation could also contribute to this phenomenon as many of the CPs form short rhizomes. As a result, such offsprings dominate the community around their putative mother plants.

Symbiotic $N_{2}$ fixation of leguminous plants as a possible determining factor of species composition

In many other studies, co-adaptation resulted in a close relationship between legumes and certain grass species in permanent temperate grassland communities (Turkington and Harper 1979a, 1979b; Turkington 1989; Lüscher and Jacquard 1991; Lüscher et al. 1992). In this study, legumes as CPs seem to have a determining effect on the surrounding species (Table 2). As a mechanistic explanation, the most important positive interaction between a legume and its neighbours may be 
Table 4. Backtransformed probabilities of logistic regression for the prediction of the central plant (CP) through the neighbouring plants (radius of $5 \mathrm{~cm}$ ) at the altitude of $1900 \mathbf{~ m}$ a.s.l. $(1900 \mathrm{~m})$.

\begin{tabular}{|c|c|c|c|c|c|}
\hline Central plant & Trifolium pratense & Lotus corniculatus & Phleum alpinum & Potentilla erecta & \\
\hline $\mathrm{N}$ indicator value ${ }^{\mathrm{a}}$ & 3 & 3 & 4 & 2 & $n$ \\
\hline Model A, Intercept & $0.169^{* * * *}$ & $0.244 * * * *$ & $0.403 \mathrm{~ns}$ & $0.335^{* *}$ & \\
\hline Trifolium pratense & $0.311 * * * *$ & $0.202 *$ & $0.270 * * *$ & $0.202^{* *}$ & 250 \\
\hline Lotus corniculatus & $0.166 \mathrm{~ns}$ & $0.289^{*}$ & $0.374 \mathrm{~ns}$ & $0.263^{*}$ & 141 \\
\hline Phleum alpinum & $0.161 \mathrm{~ns}$ & $0.232 \mathrm{~ns}$ & $0.418 \mathrm{~ns}$ & $0.353 \mathrm{~ns}$ & 636 \\
\hline Potentilla erecta & $0.162 \mathrm{~ns}$ & $0.265 \dagger$ & $0.400 \mathrm{~ns}$ & $0.306 \dagger$ & 515 \\
\hline Model B, Intercept & $0.280 * *$ & $0.107 * * * *$ & $0.427 \mathrm{~ns}$ & $0.409 \mathrm{~ns}$ & \\
\hline Trifolium pratense & $0.462 * * * *$ & $0.089 \dagger$ & $0.287 * * *$ & $0.255^{* *}$ & 250 \\
\hline Lotus corniculatus & $0.279 \mathrm{~ns}$ & $0.130^{*}$ & $0.410 \mathrm{~ns}$ & $0.323^{*}$ & 141 \\
\hline Phleum alpinum & $0.263 \mathrm{~ns}$ & $0.105 \mathrm{~ns}$ & $0.446 \mathrm{~ns}$ & $0.426 \mathrm{~ns}$ & 636 \\
\hline Potentilla erecta & $0.269 \mathrm{~ns}$ & $0.122 *$ & $0.428 \mathrm{~ns}$ & $0.379 \dagger$ & 515 \\
\hline Agrostis tenuis & $0.231 *$ & $0.130^{*}$ & - & - & 318 \\
\hline Festuca rubra & - & - & - & $0.379 \dagger$ & 557 \\
\hline Leontodon helveticus & - & $0.178 * *$ & - & $0.257 \dagger$ & 53 \\
\hline Nardus stricta & $0.259^{*}$ & $0.118^{* *}$ & $0.406^{*}$ & - & 1244 \\
\hline Trifolium repens & - & - & $0.462 \dagger$ & - & 354 \\
\hline$p$-value (Model $\mathrm{A}$ ) & $* * * *$ & $* *$ & $* * * *$ & $* * * *$ & \\
\hline$R^{2}$ (Model A) & 33.9 & 7.1 & 15.1 & 14.3 & \\
\hline$p$-value (Model B) & $* * * *$ & $* * * *$ & $* * * *$ & $* * * *$ & \\
\hline$R^{2}$ (Model B) & 37.4 & 16.8 & 18.8 & 18.0 & \\
\hline Likelihood ratio test (Model A versus B) & ** & $* * * *$ & * & * & \\
\hline
\end{tabular}

ns: $p>0.1 ; \dagger p \leq 0.1 ;{ }^{*} p \leq 0.05 ; * * p \leq 0.01 ; * * * p \leq 0.001 ; * * * * p \leq 0.0001 ;-:$ term was not included in the final model. ${ }^{\mathrm{a}}$ Landolt (1977).

In model A, only the same species as the four CPs were evaluated as predictor species (neighbour species). In model B, additional neighbour species with distinct effects $(p<0.1)$ were selected by a stepwise procedure. Further details see Table 2a.

the transfer of symbiotically fixed $\mathrm{N}$ (Hartwig 1998). A previous study showed that symbiotic $\mathrm{N}_{2}$ fixation is important for the $\mathrm{N}$ balance of the various legume species in the study area up to the highest altitudes of legume growth (Jacot et al. 2000a). A species that is efficient in fixing $\mathrm{N}_{2}$ usually has a $\delta^{15} \mathrm{~N}$ close to 0 (Table 3) because, per definition, the fixed $\mathrm{N}$ derived from the atmosphere has a $\delta^{15} \mathrm{~N}$ value of 0 . When a non leguminous species profits from the $\mathrm{N}$ that originated from the legume, its $\delta^{15} \mathrm{~N}$ value would, thus, become diluted and expected to be close to zero. The observed decrease in the $\delta^{15} \mathrm{~N}$ values of non leguminous species that grow near to legumes compared to non leguminous species growing far from legumes suggests an apparent transfer (mineralised legume N) of symbiotically fixed $\mathrm{N}$ (Table 3). For example, Agrostis tenuis at $900 \mathrm{~m}$ a.s.l., which was strongly associated with Lotus corniculatus (Table 2), had a $\delta^{15} \mathrm{~N}$ value of 2.10 when it grew near leguminous plants and a value of 3.59 in an area far from legumes, indicating that A. tenuis was influenced by symbiotic $\mathrm{N}$ that was fixed originally by the leguminous plant. This suggests that a relatively $\mathrm{N}$-rich environment, as created by symbiotic $\mathrm{N}_{2}$ fixation in the neighbourhood of L. corniculatus, may give $A$. tenuis a competitive advantage. Although this result suggests that there may be a transfer of $\mathrm{N}$, the $\delta^{15} \mathrm{~N}$ values were too low to quantify. $\delta^{15} \mathrm{~N}$ values around 6.0 are necessary since the accuracy of the method decreases when the $\delta^{15} \mathrm{~N}$ values are low (Domenach and Corman 1984; Ledgard and Peoples 1988; Peoples et al. 1989; Jacot et al. 2000a).

The concentration of $\mathrm{N}$ in the legumes in this study was consistently higher than in non leguminous species (Jacot et al. 2000b), presumably leading to a higher $\mathrm{N}$ concentration in the litter. The importance of the quality of litter (decomposition) was demonstrated for grass species by Wedin and Tilman (1990); the dramatic divergence of net mineralization rates of $\mathrm{N}$ in initially identical soil under five perennial grass species showed a potential for strong interactions among the species composition and $\mathrm{N}$ cycling in the ecosystem. Likewise, Thomas and Bowman (1998) showed that extractable soil mineral $\mathrm{N}$ was significantly higher in legume patches than in patches 
Table 5. Backtransformed probabilities of logistic regression for the prediction of the central plant (CP) through the neighbouring plants (radius of $5 \mathrm{~cm}$ ) at the altitude of $\mathbf{2 1 0 0} \mathbf{~ m}$ a.s.l. $(2100 \mathrm{~m}$ ).

\begin{tabular}{|c|c|c|c|c|c|}
\hline Central plant & Trifolium nivale & Lotus alpinus & Leontodon helveticus & Potentilla erecta & \\
\hline $\mathrm{N}$ indicator value $\mathrm{a}^{\mathrm{a}}$ & 3 & 3 & 2 & 2 & $n$ \\
\hline Model A, Intercept & $0.195^{* * * *}$ & $0.257^{* *}$ & $0.288^{* *}$ & $0.279 * *$ & \\
\hline Trifolium nivale & $0.332^{* * * *}$ & $0.127 *$ & $0.270 \mathrm{~ns}$ & $0.189^{*}$ & 101 \\
\hline Lotus alpinus & $0.194 \mathrm{~ns}$ & $0.282 \mathrm{~ns}$ & $0.270 \mathrm{~ns}$ & $0.273 \mathrm{~ns}$ & 180 \\
\hline Leontodon helveticus & $0.184 \mathrm{~ns}$ & $0.246 \mathrm{~ns}$ & $0.303 \mathrm{~ns}$ & $0.285 \mathrm{~ns}$ & 238 \\
\hline Potentilla erecta & $0.184 \mathrm{~ns}$ & $0.271 \mathrm{~ns}$ & $0.272 \mathrm{~ns}$ & $0.284 \mathrm{~ns}$ & 329 \\
\hline Model B, Intercept & $0.170^{* * * *}$ & $0.257^{* *}$ & $0.225^{* * *}$ & $0.363 \mathrm{~ns}$ & \\
\hline Trifolium nivale & $0.303^{* * * *}$ & $0.127 *$ & $0.201 \mathrm{~ns}$ & $0.265 \dagger$ & 101 \\
\hline Lotus alpinus & $0.169 \mathrm{~ns}$ & $0.282 \mathrm{~ns}$ & $0.210 \mathrm{~ns}$ & $0.346 \mathrm{~ns}$ & 180 \\
\hline Leontodon helveticus & $0.165 \mathrm{~ns}$ & $0.246 \mathrm{~ns}$ & $0.241 \mathrm{~ns}$ & $0.397 \mathrm{~ns}$ & 238 \\
\hline Potentilla erecta & $0.157 \mathrm{~ns}$ & $0.271 \mathrm{~ns}$ & $0.214 \mathrm{~ns}$ & $0.362 \mathrm{~ns}$ & 329 \\
\hline Alchemilla vulgaris & - & - & $0.281 \dagger$ & - & 53 \\
\hline Campanula rotundifolia & - & - & - & $0.231 \dagger$ & 63 \\
\hline Geum montanum & - & - & $0.301 \dagger$ & $0.221 *$ & 62 \\
\hline Soldanella pusilla & - & - & - & $0.053^{*}$ & 43 \\
\hline Thymus polytrichus & $0.296^{*}$ & - & - & - & 25 \\
\hline Vaccinium myrtillus & - & - & - & $0.457^{*}$ & 86 \\
\hline$p$-value (Model A) & $* * * *$ & ** & ns & ns & \\
\hline$R^{2}($ Model A) & 24.6 & 13.4 & 1.9 & 6.7 & \\
\hline$p$-value (Model B) & $* * * *$ & $* *$ & ns & $* * * *$ & \\
\hline$R^{2}($ Model $\mathrm{B})$ & 29.2 & 13.4 & 7.7 & 27.4 & \\
\hline Likelihood ratio test (Model A versus B) & * & - & * & $* * * *$ & \\
\hline
\end{tabular}

ns: $p>0.1 ; \dagger p \leq 0.1 ; * p \leq 0.05 ; * * p \leq 0.01 ; * * p \leq 0.001 ; * * * * \leq 0.0001 ;-:$ term was not included in the final model. ${ }^{\mathrm{a}}$ Landolt (1977).

In model A, only the same species as the four CPs were evaluated as predictor species (neighbour species). In model B, additional neighbour species with distinct effects $(p<0.1)$ were selected by a stepwise procedure. Further details see Table 2 a.

Table 6. $\delta^{15} \mathrm{~N}$ of legumes and plant species near legumes (Trifolium pratense/nivale and Lotus corniculatus/alpinus) or in an area far from legumes at four altitudes in $1998(n=12)$.

\begin{tabular}{|c|c|c|c|c|c|c|}
\hline Altitude (m a.s.l.) & Plant species & Near legumes & & Far from legumes & SE & $p$ \\
\hline & & & $\delta^{15} \mathrm{~N}$ & & & \\
\hline \multirow[t]{4}{*}{900} & Legumes & & -0.18 & & 0.17 & \\
\hline & Agrostis tenuis & 2.10 & & 3.59 & 0.16 & $* * *$ \\
\hline & Trisetum flavescens & 2.00 & & 2.29 & 0.28 & ns \\
\hline & Leontodon hispidus & 3.88 & & 4.07 & 0.22 & ns \\
\hline \multirow[t]{4}{*}{1380} & Legumes & & 1.5 & & 0.66 & \\
\hline & Festuca rubra & 4.48 & & 2.85 & 0.46 & * \\
\hline & Trisetum flavescens & 1.63 & & 0.78 & 0.24 & ns \\
\hline & Leontodon hispidus & 4.59 & & 2.95 & 0.41 & $*$ \\
\hline \multirow[t]{4}{*}{1900} & Legumes & & -0.59 & & 0.16 & \\
\hline & Festuca rubra & -0.65 & & 1.87 & 0.28 & $* * *$ \\
\hline & Nardus stricta & 0.42 & & 2.19 & 0.58 & $*$ \\
\hline & Potentilla aurea & -0.26 & & 0.09 & 0.30 & ns \\
\hline \multirow[t]{4}{*}{2100} & Legumes & & -0.20 & & 0.16 & \\
\hline & Festuca rubra & 0.71 & & -2.24 & $0.46^{* *}$ & \\
\hline & Leontodon helveticus & -1.82 & & -3.38 & $0.20 * * *$ & \\
\hline & Potentilla aurea & -2.78 & & -3.90 & $0.29 * *$ & \\
\hline
\end{tabular}

ns: $p>0.1 ; \dagger p \leq 0.1 ; * p \leq 0.05 ; * * p \leq 0.01 ; * * * \leq 0.001 ; * * * p \leq 0.0001$.

of soil without legumes. In this respect, the high rate of symbiotic $\mathrm{N}_{2}$ fixation of legumes measured at these sites (Jacot et al. 2000a) would result in greater amounts of mineral $\mathrm{N}$ being left for the associated non leguminous plants. The finding that the average $\mathrm{N}$ indicator values of plant species in 
Table 7. Medians of nitrogen $(\mathrm{N})$ and temperature $(T)$ indicator value (Landolt 1977) of all plant species (Table 1$) \mathrm{close}(r=5 \mathrm{~cm})$ to different central plant species (CP) (two legumes, a high $\mathrm{N}$ indicator and a low $\mathrm{N}$ indicator) at four altitudes in 1996 and 1997.

\begin{tabular}{|c|c|c|c|c|c|c|}
\hline Central plant & Trifolium pratense/nivale & Lotus corniculatus/ alpinus & high $\mathrm{N}$ indicator & low $\mathrm{N}$ indicator & & \\
\hline (a) Altitude (m a.s.l.) & $\mathrm{N}$ indicator value & & & & $p(\mathrm{CP})$ & $\mathrm{n}$ \\
\hline 900 & $3.20^{\mathrm{a}}$ & $3.17^{\mathrm{a}}$ & $3.26^{\mathrm{a}}$ & $2.83^{\mathrm{b}}$ & $* * * *$ & 77 \\
\hline 1380 & 3.25 & 3.31 & 3.30 & 3.25 & ns & 77 \\
\hline 1900 & $2.77^{\mathrm{a}}$ & $2.55^{\mathrm{b}}$ & $2.68^{\mathrm{ac}}$ & $2.52^{\mathrm{bc}}$ & $* * *$ & 80 \\
\hline 2100 & 2.34 & 2.27 & $\mathrm{Nm}$ & 2.24 & ns & 40 \\
\hline (b) Altitude (m a.s.l.) & $T$ indicator value & & & & $p(\mathrm{CP})$ & $\mathrm{n}$ \\
\hline 900 & $3.25^{\mathrm{ab}}$ & $3.18^{\mathrm{b}}$ & $3.33^{\mathrm{a}}$ & $3.17^{\mathrm{b}}$ & $* * * *$ & 77 \\
\hline 1380 & 3.00 & 3.05 & 3.03 & 3.00 & ns & 77 \\
\hline 1900 & 2.23 & 2.24 & 2.11 & 2.17 & ns & 80 \\
\hline 2100 & $1.73^{\mathrm{b}}$ & $1.85^{\mathrm{a}}$ & $\mathrm{Nm}$ & $2.00^{\mathrm{a}}$ & $* * *$ & 40 \\
\hline
\end{tabular}

nm: not measured; ns: $p>0.05 ; p \leq 0.1 ; * p \leq 0.05 ; * * p \leq 0.01 ; * * * p \leq 0.001 ; * * * * \leq 0.0001$.

the vicinity of legumes as CPs were generally higher than around the low $\mathrm{N}$ indicator CPs (Table 4a), is consistent with this interpretation.

The fact that some $\delta^{15} \mathrm{~N}$ values of non leguminous species were well above zero when growing near to legumes, e.g., at $1380 \mathrm{~m}$ a.s.l., indicates that spatial $\mathrm{N}$ uptake may also influence the $\delta^{15} \mathrm{~N}$ values in the vicinity of legumes \& non leguminous species. Moreover, the effects of management such as animal grazing or spreading of manure (e.g. from concentrate fed animals) may affect the $\delta^{15} \mathrm{~N}$ in such a way it can no longer be used to determine symbiotic $\mathrm{N}_{2}$ fixation or apparent $\mathrm{N}$ transfer.

Another indication for the benefit of legumeoriginated $\mathrm{N}$ for non leguminous plants could be a comparison of $\mathrm{N}$ concentrations between those growing in the neighbourhood of legumes with those growing in the neighbourhood of non leguminous plants. However, one has to be aware that available soil $\mathrm{N}$ affects also the development of plants which itself interferes with their $\mathrm{N}$ concentration in tissue. Indeed, our results show no clear pattern (data not shown); in tendency, non leguminous plants growing in the neighbourhood of legumes have even a lower $\mathrm{N}$ concentration compared to those growing in the neighbourhood of non leguminous plants.

\section{Other biotic or abiotic mechanisms determining species composition in the near neighbourhood of CPs}

In addition to the beneficial effect of $\mathrm{N}$, dissimilarity in size, growth habit, plant spacing or physiological and morphological adjustments
(Soussana and Lafarga 1998) as well as a temporal partitioning of the root and shoot zone may also contribute to the co-existence of certain plant species (Gimingham 1978). We found that species that indicate smaller amounts of soil $\mathrm{N}$ (e.g., Festuca rubra) coexist with species that indicate N-rich conditions (e.g., Dactylis glomerata); similarly, tall species (e.g., Silene vulgaris) often grow close to short species (e.g., Trifolium repens) (Table 2). At the highest altitude, the vicinity of Potentilla erecta was dominated to a great extent by Vaccinium myrtillus (Table 2). This indicates that certain herbaceous species that grow near to shrubby species may have a protective benefit from the latter. Such 'complementary strategies' may enable species to coexist and may in part be responsible for the stability of certain aggregations of species.

Beside positive plant-plant interactions, competition may also contribute to species composition. At $900 \mathrm{~m}$ a.s.1., e.g., Silene vulgaris did not usually grow close to Trifolium pratense, Lotus corniculatus and Dactylis glomerata (Table 2), indicating competition for below-ground resources and/or above-ground resources (light).

Legumes may not only influence neighbouring plant species through $\mathrm{N}$ availability; Thomas and Bowman (1998) showed that extractable P was lower in the soil of legume patches than in the soil where other plant species grew. This may be the result of a greater uptake of $\mathrm{P}$ by legumes relative to non leguminous plants. The fact that Agrostis tenuis for example was not associated with Trifolium pratense at $900 \mathrm{~m}$. a.s.l. - but was associated with Lotus corniculatus - (Table 2) clearly indicates that symbiotically fixed $\mathrm{N}$ is not the only 
determinant of the pattern of plants with respect to the neighbourhood of legumes.

Spatial heterogeneity in species composition may also be the result of microtopographic diversity (e.g., soil depth, texture and roughness of the surface) or microclimatic conditions (Fransen et al. 2001). The influence of such factors may increase at higher altitudes where soil is shallower, thus resulting in a rougher surface and many niches with relatively deep and very shallow soil patches (Franz 1987). This is also evident from the fact, that with increasing altitude, the occurrence of legumes becomes increasingly patchy (Jacot et al. 2000a, b). The effect of abiotic factors may be one of the reasons why, for example, the vicinity of Trifolium pratense was not characterised by the same set of species along the altitudinal gradient (Table 2). Different environmental conditions lead to site-specific plant species, e.g., with a different growth form and different competitive behaviour.

Soil nutrient heterogeneity may likewise contribute to species composition. This is evident from our data, which demonstrate that $\mathrm{N}$ availability was apparently highest close to the $\mathrm{N}$ indicator $\mathrm{CP}$ at $900 \mathrm{~m}$ a.s.l., whereas apparent $\mathrm{N}$ availability was highest close to Trifolium pratense/nivale at 1900 and $2100 \mathrm{~m}$ a.s.1. (Table 4a). This soil $\mathrm{N}$ heterogeneity may be the result of differences in the soil environment (soil depth, nutrient input, rate of leaching) and of the species which regulates soil mineral $\mathrm{N}$.

In particular, local deposits of dung and urine at higher altitudes may create pockets of high available $\mathrm{N}$ in the soil. For example, we observed that Phleum alpinum grows more vigorous close to deposits of dung at $2300 \mathrm{~m}$ a.s.l. This indicates that this species, which requires large amounts of $\mathrm{N}$, is mainly competitive at high altitudes due to input of $\mathrm{N}$ through dung and, thus, contributes to species composition.

The distinct $T$ values of the CPs (Table 4b) indicate that small-scale differences in temperature conditions may exist in a sward leading to respective patterning of plant species.

The strength of the association between a CP and its neighbouring species was lower at higher altitudes (Table 2); moreover, the number of plants associated significantly with certain CPs decreased as well. This may indicate that biotic effects - mainly decisive for the composition of plant species at lower sites - become increasingly overridden by abiotic factors, such as microclimatic (e.g. (Table 4b) and/or edaphic conditions, at higher altitudes.

\section{Conclusion}

Mechanisms, such as narrow-range seed and/or vegetative propagation, may affect plant species patterning. Moreover, this study shows that, through symbiotic $\mathrm{N}_{2}$ fixation, legumes may affect the patterning of plant species in grassland ecosystems by providing extra nitrogen to their near surrounding. However, other biotic or abiotic factors may be decisive for the composition of plant species.

\section{Acknowledgments}

This study was supported by a grant from the Swiss National Science Foundation (31-45626.95) to U.A.H. We are indebted to Sabina Keller, Kirsten Kopp and Doris Huber for their assistance. We thank Prof. Dr. Matthias Baltisberger (Institute of Geobotany, ETH Zurich) for checking the determinations of plant species, Garth Parry (University of Saskatchewan, Saskatoon, Canada) for conducting the ${ }^{15} \mathrm{~N}$ analysis and Dr. Lisa Pritscher (Institute of Mathematics, ETH Zurich) for statistical support. We also thank Andreas Naegeli of the extension service of the 'Bündner Oberländer Bauernverband' and the community and farmers in Sumvitg and Trun for their co-operation. We thank Prof. Peter J. Edwards for critically reading a draft of the manuscript and Marcia Schoenberg for checking the English.

\section{References}

Bertness M.D. and Callaway R.M. 1994. Positive interactions in communities. Trend Ecol. Evol. 9: 191-193.

Boller B.C. and Nösberger J. 1988. Influence of dissimilarities in temporal and spatial $\mathrm{N}$-uptake pattern on ${ }^{15} \mathrm{~N}$-based estimates of fixation and transfer of $\mathrm{N}$ in ryegrass-clover mixtures. Plant Soil 112: 167-175.

Cabin R.J. and Marshall D.L. 2000. The demographic role of seed banks. I. Spatial and temporal comparisons of belowand above-ground populations of the desert mustard Lesquerella fendleri. J. Ecol. 88: 283-292.

Callaway R.M. 1995. Positive interactions among plants. Bot. Rev. 61: 306-349. 
Chapin F.S.III, Walker L.R., Fastie C.L. and Sharman L.C. 1994. Mechanism of primary succession following deglaciation at Glacier Bay, Alaska. Ecol. Monogr. 64: 149-175.

Domenach A.M. and Corman A. 1984. Dinitrogen fixation by field grown soybeans, statistical analyses of variations in delta ${ }^{15} \mathrm{~N}$ and proposed sampling procedure. Plant Soil 78: 301-313.

Fransen B., de Kroon H. and Berendse F. 2001. Soil nutrient heterogeneity alters competition between two perennial grass species. Ecology 82: 2534-2546.

Franz H. 1987. Ökologie des hochalpinen Raumes in den Alpen. Verhandlungen der Gesellschaft für Ökologie 15: $11-18$.

Gimingham C.H. 1978. Calluna and its associated species, some aspects of coexistence in communities. Vegetatio 36: 179-186.

Hacker S.D. and Gaines S.D. 1997. Some implications of direct positive interaction for community species diversity. Ecology 78: 1990-2003.

Hartwig U.A. 1998. The regulation of symbiotic $\mathrm{N}_{2}$ fixation, a conceptual model of $\mathrm{N}$ feedback from the ecosystem to the gene expression level. Perspect. Plant Ecol. Evol. Syst. 1: 92 120.

Hebeisen T., Lüscher A., Zanetti S., Fischer B.U., Hartwig U.A., Frehner M., Hendrey G.R., Blum H. and Nösberger J. 1997. Growth response of Trifolium repens L. and Lolium perenne $\mathrm{L}$. as monocultures and bi-species mixture to free air $\mathrm{CO}_{2}$ enrichment and management. Glob. Change Biol. 3: 149-160.

Hess H.E., Landolt E. and Hirzel R. 1984. Bestimmungsschlüssel zur Flora der Schweiz und angrenzender Gebiete, 2nd ed. Birkhäuser Verlag Basel und Stuttgart, pp. 657.

Hogh-Jensen H. and Schjoerring J.K. 1994. Measurement of biological dinitrogen fixation in grassland, Comparison of the enriched ${ }^{15} \mathrm{~N}$ dilution and the natural abundance methods at different nitrogen application rates and defoliation frequencies. Plant Soil 166: 153-163.

Jacot K.A., Lüscher A., Nösberger J. and Hartwig U.A. 2000a. Symbiotic $\mathrm{N}_{2}$ fixation of various legume species along an altitudinal gradient in the Swiss Alps. Soil Biol. Biochem. 32: 1043-1052.

Jacot K.A., Lüscher, Nösberger J. and Hartwig U.A. 2000b. The relative contribution of symbiotic $\mathrm{N}_{2}$ fixation and other nitrogen sources to grassland ecosystems along an altitudinal gradient in the Alps. Plant Soil 225: 201-211.

Kershaw K.A.I. 1958. An investigation of the structure of a grassland community. J. Ecol. 46: 571.

Kershaw K.A.I. 1959. An investigation of the structure of a grassland community. J. Ecol. 47: 31-52.

Kikvidze Z. 1993. Plant Species associations in alpine-subnival vegetation patches in the Central Caucasus. J. Veget. Sci. 4: 297-302.

Landolt E. 1977. Ökologische Zeigerwerte zur Schweizer Flora. Veröffentlichungen des Geobotanischen Institutes der Eidgenössischen Techischen Hochschule, Stiftung Rübel, Zürich 64: 83-169.
Lawrence D., Schoenike R., Quispel A. and Bond G. 1967. The role of Dryas drummondi in vegetation development following ice regression at Glacier Bay, Alaska, with special reference to its nitrogen fixation by root nodules. J. Ecol. 55: 793-813.

Ledgard S.F. and Peoples M.B. 1988. Measurement of nitrogen fixation in the field. In: Wilson J.R. (ed.), Advances in Nitrogen Cycling in Agricultural Ecosystems. Wallingford Cab Int, UK, pp. 351-367.

Lüscher A., Connolly J. and Jacquard P. 1992. Neighbour specificity between Lolium perenne and Trifolium repens from a natural pasture. Oecologia 91: 404-409.

Lüscher A. and Jacquard P. 1991. Coevolution between interspecific plant competitors? Trend Ecol. Evol. 6: 355-358.

Morris W.F. and Wood D.M. 1989. The role of lupine in succession on Mount St. Helens, facilitation or inhibition? Ecology 70: 697-703.

Peoples M.B., Faizah A.W., Rerkasem B. and Herridge D.F. 1989. Methods for evaluating nitrogen fixation by nodulated legumes in the field. ACIAR, Canberra, pp. 72.

Seresinhe T., Hartwig U.A., Kessler W. and Nösberger J. 1994. Symbiotic nitrogen fixation of white clover in a mixed sward is not limited by height of repeated cutting. J. Agron. Crop Sci. 172: 1009-1014.

Shearer G. and Kohl D.H. 1986. $\mathrm{N}_{2}$ fixation in field settings, estimations based on natural abundance. Aust. J. Plant Physiol. 13: 699-744.

Soussana J.F. and Lafarga M. 1998. Competition for resources between neighbouring species and patch scale vegetation dynamics in temperate grasslands. Annales de Zootechnie 47: 371-382.

Thomas B.D. and Bowman W.D. 1998. Influence of $\mathrm{N}_{2}$-fixing Trifolium on plant species composition and biomass production in alpine tundra. Oecologia 115: 26-31.

Turkington R. and Harper J.L. 1979a. The growth, distribution and neighbour relationships of Trifolium repens in a permanent pasture, I Ordination pattern and contact. J. Ecol. 67: 201-218.

Turkington R. and Harper J.L. 1979b. The growth, distribution and neighbour relationships of Trifolium repens in a permanent pasture, II Inter- and intra-specific contact. J. Ecol. 67: 218-230.

Turkington R., Harper J.L., de Jong O. and Aarssen L.W. 1985. A reanalysis of interspecific association in an old pasture. J. Ecol. 73: 123-131.

Turkington R. 1989. The growth, distribution and neighbour relationships of Trifolium repens in a permanent pasture, V The coevolution of competitors. J. Ecol. 77: 717-733.

Vitousek P.M. and Howarth R.W. 1991. Nitrogen limitation on land and in the sea, how can it occur? Biogeochemistry 13: $87-115$.

Wedin D.A. and Tilman D. 1990. Species effect on nitrogen cycling, a test with perennial grasses. Oecologia 84: 433-441.

Zanetti S., Hartwig U.A., van Kessel C., Lüscher A., Hebeisen T., Frehner M., Fischer B.U., Hendrey G.R., Blum H. and Nösberger J. 1997. Does nitrogen restrict the $\mathrm{CO}_{2}$ response of fertile grassland lacking legumes? Oecologia 112: 17-25. 